ББК 63.4

\author{
Организация конференциии и издание материалов проведень \\ при финансовой поддержке Российского фонда фундаментальных исследований, \\ проект № 19-09-20008
}

Утверждено к печати Ученым советом ИИМК РАН

Редакционная коллегия тома I: В. А. Алёкшин, Л. Б. Кирчо (отв. редакторы),

В. П. Никоноров, В. Я. Стёганцева; В. В. Терёхина

Рецензенты: д. и. н. Л. Б. Вишняцкий, д. и. н. А. А. Выборнов

Программный комитет конференции: академик РАН, д. и. н., проф. М. Б. Пиотровский

(Государственный Эрмитаж, почетный председатель); д. и. н. В. А. Лапшин (ИИМК РАН, председатель); д. и. н. А. В. Головнёв (МАЭ РАН, сопредседатель); д. и. н. В. А. Дергачёв (Высшая антропологическая школа, Молдова, сопредседатель); д. и. н. И. Ф. Попова (ИВР РАН, сопредседатель); академик АН Республики Узбекистан, д. и. н., проф. Э. В. Ртвеладзе (сопредседатель); к. и. н. А. В. Поляков (ИИМК РАН, зам. председателя); к. и. н. В. А. Алёкшин (ИИМК РАН, зам. председателя); д. и. н. Ю. Е. Берёзкин (МАЭ РАН); Dr., Prof. Н. Бороффка (Германский археологический институт, Германия); В. С. Бочкарёв (ИИМК РАН); Dr. Э. Кайзер (Свободный университет Берлина, Германия); к. и. н. М. Т. Кашуба (ИИМК РАН); д. и. н. Л. Б. Кирчо (ИИМК РАН); к. и. н. А. В. Кияшко (Южный федеральный университет); к. и. н. П. Ф. Кузнецов (СГСПУ);

к. и. н. Н. М. Малов (СНИГУ); к. и. н. В. П. Никоноров (ИИМК РАН); Ю. Ю. Пиотровский

(Государственный Эрмитаж); д. и. н., проф. Д. Г. Савинов (Институт истории СПбГУ);

к. и. н. В. Н. Седых (Институт истории СПбГУ); к. и. н. Н. Н. Скакун (ИИМК РАН);

к. и. н. Н. Ф. Соловьёва (ИИМК РАН); к. и. н. А. И. Торгоев (Государственный Эрмитаж); к. и. н. Е. А. Черлёнок (Институт истории СПбГУ)

Организационный комитет конференции: к. и. н. А. В. Поляков (ИИМК РАН, председатель);

к. и. н. В. А. Алёкшин (ИИМК РАН, зам. председателя); В. С. Бочкарёв (ИИМК РАН); ); к. и. н. М. Т. Кашуба (ИИМК РАН); д. и. н. Л. Б. Кирчо (ИИМК РАН);

А. И. Климушина (ИИМК РАН, отв. секретарь); к. и. н. В. П. Никоноров (ИИМК РАН); Ю. Ю. Пиотровский (Государственный Эрмитаж); В. Я. Стёганцева (ИИМК РАН); В. В. Терёхина

(ИИМК РАН, МАЭ РАН, отв. секретарь); к. и. н. Е. С. Ткач (ИИМК РАН); И. Ж. Тутаева (Государственный Эрмитаж); к. и. н. Е. А. Черлёнок (Институт истории СПбГУ)

Древности Восточной Европы, Центральной Азии и Южной Сибири в контексте связей и взаимодействий в евразийском культурном пространстве (новые данные и концепции): Материалы Международной конференции, 18-22 ноября 2019 г., Санкт-Петербург. Т. I. Древняя Центральная Азия в контексте евразийского культурного пространства (новые данные и концепции). К 90-летию со дня рождения патриарха евразийской археологии Вадима Михайловича Массона. - СПб.: ИИМК РАН, Невская Типография, 2019. — 291 с.

ISBN 978-5-907053-34-2

DOI 10.31600/978-5-907053-34-2 


\title{
LOCK-SHAPED STONE HAND-BAGS (PIERRE ANSÉES) FROM CENTRAL AND MIDDLE ASIA: TYPOLOGY, DISTRIBUTION AND NEW FINDINGS
}

\author{
Gian Luca Bonora \\ Associazione Internazionale di Studi sul Mediterraneo e l'Oriente, Rome, Italy
}

DOI: 10.31600/978-5-907053-34-2-57-58

Keywords: hand-bag stone artefacts, Bronze Age, typology, Iranian plateau, Central Asia, Eurasian steppe, Middle Asian interaction spheres.

This paper is dedicated to the study of the stone hand-bags of lock shape and other similar forms discovered across Bronze Age Eurasia. These artefacts are often called as "weights" and "pierre ansées". Information, data and measurements are collected and presented for the first time in a comprehensive paper. A preliminary typology of the artefacts divided into seven large types, with few sub-types, is then advanced. Unfortunately, most of the hand-bags have been found by change, lacking useful information to understand and reconstruct their original function whether ritual, social or economic - that remains enigmatic. The earliest of them were found in proto-chalcolithic and chalcolithic sites of south Turkmenistan (Алёкшин 1973), as well as few rough hand-bags, distinguished by a solid, thick body and unpolished surfaces, were found by E. Schmidt (Schmidt 1937) in a Period IIB context of Tepe Hissar (north-eastern Iran), datable to the last centuries of the $4^{\text {th }}$ millennium BC. Two identical rough handled weights were recently recovered on the surface of a minor settlement in Sistan, not far from Shahr-i Sokhta, in association with pottery of the early $3^{\text {rd }}$ millennium BC. However, the period of their greatest diffusion is comprised between the mid- $3^{\text {rd }}$ and the mid $-2^{\text {nd }}$ millennium BC, as confirmed by the discovery of some hand-bags in stratigraphic contexts of farmers settlements located in northern and southeaster Iran, southern Turkmenistan, Iraq and Uzbekistan.

Recently, a large number of these beautiful and complex artefacts have been illegally excavated in the plundered graveyards of the Halil Rud, southern Iran (Majiidzadeh 2003). Only few specimens, unfortunately without context, were later recovered by the Iranian authorities. What was their symbolic meaning and their actual function in the funerary rituals? Together with clorite and schist staffs and miniature columns, "weights" of variable forms, including finely figurative stone hand-bags, had probably a very specific function in the funerary rituals of the elites that, between the late $3^{\text {rd }}$ millennium and the middle of the $2^{\text {nd }}$ millennium BC, were diffused across Eastern Iran, Bactria, Central Asia and northern Baluchistan. These stone artefacts played an unknown but evidently pervasive ideological function.

Moreover, other hand-bags have been identified by the author of this paper in the storerooms of different museums in southern Kazakhstan and Uzbekistan extending their area of diffusion northward, toward the cultural world of the Eurasian steppes. For example, a lockshaped undecorated handbag (Fig. 1), made of grayish granite found by chance in 1984 in the Lenin village of the Kordaj district, at the border between Kazakhstan and Kyrgyzstan, is displayed today in a showcase of the Historical Museum of Zhambyl (formerly, Taraz) in south Kazakhstan. Others are stored in the Central State Museum of Almaty as well as some specimens are in the Regional Museum of History of Ferghana (Uzbekistan).

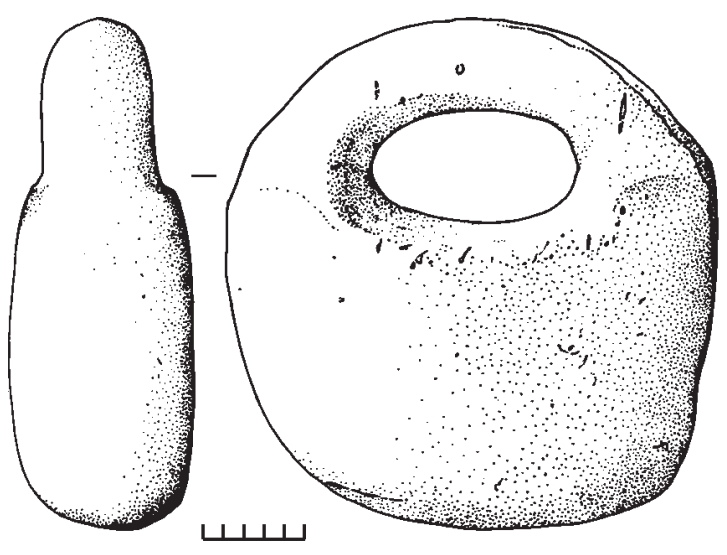

Fig. 1. Lock-shaped handbag from the Lenin village of the Kurday ditrict, at the border between Kazakhstan and Kyrgyzstan 
A chronological attribution to the second half of the late $3^{\text {rd }}$ millennium $\mathrm{BC}$ is here put forth for these Kazakhstan and Uzbekistan handbags chance finds. As witnessed further by the beautiful lock-shaped handbag or amulet from Soch, in Ferghana, characterised by fine figurative zoomorphic decoration and inserts containing coloured stones, they may testify the earliest attempts made by southern Central Asian surveyors to explore and exploit the southern Central Asian steppes in search for metal and other resources.

Aware that the geographical definition of Oxus Civilisation is a matter of broad scientific debate, the study of this class of objects allows to shed some new light on the socio-economic and cultural contacts between the settled farming communities of Middle Asia and the mobile groups of cattle breeders widespread across the Eurasian steppes.

\title{
References
}

Алёкшин В. А. 1973. Каменные гири сдревнеземледельческих поселений южной Туркмении // CA. № 4. C. 238-242.

Madjidzadeh Y. 2003. Jiroft: The Earliest Oriental Civilization. Tehran.

Schmidt E. F. 1937. Excavations at Tepe Hissar Damghan. Philadelphia.

\section{КАМЕННЫЕ “СУМОЧКИ В ФОРМЕ ЗАМКА» (PIERRE ANSÉES) ИЗ ЦЕНТРАЛЬНОЙ И СРЕДНЕЙ АЗИИ: ТИПОЛОГИЯ, РАСПРОСТРАНЕНИЕ И НОВЫЕ ОТКРЫТИЯ}

\author{
Ж. Л. Бонора \\ Международная ассоииация исследований в Средиземноморье и на Востоке, \\ Рим, Италия
}

Ключевые слова: каменные артефбакты в виде «сумочек», бронзовый век, типология, Иранское плато, Центральная Азия, Евразийская степь, среднеазиатские сферы взаимодействия.

Доклад посвящен изучению каменных «сумочек в форме замка» и других подобных форм, обнаруженных на памятниках бронзового века Евразии. Самые ранние из них были найдены на протоэнеолитических и энеолитических поселениях Южного Туркменистана (Алёкшин 1973). Еще несколько «сумок» грубой работы, отличающихся твердым, толстым телом и неполированной поверхностью, были найдены Э. Шмидтом на Тепе Гиссар (Северо-Восточный Иран) в контексте IIB периода, датируемого последними веками IV тыс. до н. э. (Schmidt 1937). Однако время наибольшего их распространения приходится на середину III - середину II тыс. до н. э., что подтверждается обнаружением некоторых сумок в стратиграфических контекстах земледельческих поселений, расположенных в Северном и Юго-Восточном Иране, Южном Туркменистана, Ираке и Узбекистане. В последнее время большое количество этих красивых и сложных артефактов было незаконно выкопано на разграбленных могильниках Халил Руда на юге Ирана. Вместе с «посохами» из хлорита и сланца и миниатюрными «колонками», «гири» различных форм, в том числе и каменные «сумочки», вероятно, выполняли очень специфическую функцию в погребальных ритуалах элиты, которые в период между концом III и серединой II тыс. до н. э. были распространены по всему Восточному Ирану, Бактрии, Центральной Азии и Северному Белуджистану. Эти каменные артефакты играли неизвестную, но, очевидно, приобретавшую все большие масштабы идеологическую функцию. Кроме того, такие же «сумочки» были обнаружены автором доклада в хранилищах разных музеев в Южном Казахстане и Узбекистане, что расширяет зону их распространения на север, в направлении культурного пространства евразийских степей. 